\title{
POLA KOMUNIKASI BADAN NARKOTIKA NASIONAL DALAM MENCEGAH PENYEBARAN NARKOBA DI KOTA MEDAN
}

\author{
Achiruddin Hasibuan, Mailin \\ Program Studi Ilmu Komunikasi \\ UIN Sumatera Utara, Jl. William Iskandar Ps.V Medan Estate, Kota Medan \\ No. HP: 081265988688 \\ e-mail: achiruddinhasibuan49@gmail.com,mmailin86@gmail.com
}

Naskah diterima tanggal 29 Oktober 2020 direvisi tanggal 24 Maret 2021 disetujui tanggal 1 April 2021

\begin{abstract}
Abstrak
Tujuan dari penelitian ini adalah untuk menjelaskan pola komunikasi Islam penyuluh dalam pencegahan dan pemberantasan bahaya penyalahgunaan narkoba dikalangan remaja Kota Langsa,) untuk menjelaskan peran penyuluh dalam pencegahan dan pemberantasan bahaya penyalahgunaan narkoba dikalangan remaja Kota Langsa, untuk menjelaskan faktor-faktor penghambat dan yang mendukung dalam pencegahan dan pemberantasan bahaya penyalahgunaan narkoba dikalangan remaja Kota Langsa, dan untuk menjelaskan upaya penyuluh dalam pencegahan dan pemberantasan bahaya penyalahgunaan narkoba dikalangan remaja Kota Langsa. Penelitian ini merupakan penelitian lapangan, menggunakan metode penelitian kualitatif deskriptif. Metode deskriptif dilakukan dengan tujuan untuk mendeskripsikan, menggambarkan, atau melukiskan secara sistematis terkait bahaya dan pencegahan Narkoba di kota Medan. Teknik pengumpulan akan dilakukan dengan triangulasi (gabungan). Informan penelitian ditentukan melalui metode purposive sumpling. Teknik pengumpulan data melalui wawancara, observasi, dan dokumentasi. Hasil penelitian menunjukkan bahwa pola komunikasi ang dilakukan BNN dalam pencegahan penyebaran Narkoba di Kota Medan adalah dilakukan dengan cara berkerjasama dengan berbagai pihak, melakukan sosialisasi baik langsung maupun melalui media massa. BNN juga menggunakan bentuk komunikasi penyuluhan dalam kegiatan sosialisasi dan desiminasi yang mengajak kerjasama seluruh dan berbagai elemen dari lapisan masyarakat, sehingga upaya mewujudkan Indonesia bebas Narkoba dapat terlaksana.

Kata-kata kunci: BNN; komunikasi; narkoba; pola; tindakan preventif
\end{abstract}

\begin{abstract}
The objectives of this study were to find out how Islamic extension agents' communication patterns in the prevention and eradication of the dangers of drug abuse among Langsa City adolescents, to determine the role of instructors in the prevention and eradication of the dangers of drug abuse among the youth of Langsa City, to determine the factors- inhibiting and supporting factors in the prevention and eradication of the dangers of drug abuse among youth in Langsa City, and to determine the efforts of instructors in the prevention and eradication of the dangers of drug abuse among youth in Langsa City. His research is a field research, using descriptive qualitative research methods. Descriptive method is carried out with the aim to describe, describe, or describe systematically related to the danger and prevention of drugs in the city of Medan. The collection technique will be carried out by triangulation (combined). The research informants were determined through the purposive sumpling method. Data collection techniques through interviews, observation, and documentation. The results showed that the pattern of communication carried out by the National Narcotics Agency in preventing the spread of narcotics in Medan was carried out by collaborating with various parties, disseminating both directly and through mass media. BNN also uses a form of extension communication in dissemination and dissemination activities that invites all and various elements of society to work together so that efforts to realize a drug-free Indonesia can be carried out.
\end{abstract}

Keywords: BNN; communication; drugs; pattern; preventive action

www.journal.uniga.ac.id 


\section{Pendahuluan}

Badan Narkotika Nasional (BNN) merupakan sebuah Lembaga Pemerintah Non Kementerian (LPNK) Indonesia yang mempunyai tugas melaksanakan tugas pemerintahan di bidang pencegahan, pemberantasan, penyalahgunaan dan peredaran gelap psikotropika, prekursor, dan bahan adiktif lainnya kecuali bahan adiktif untuk tembakau dan alkohol. Dasar hukum BNN adalah Undang-Undang Nomor 35 tahun 2009 tentang Narkotika.

\section{Kegiatan Komunikasi yang} dilakukan oleh Badan Narkotika Nasional (BNN) salah satunya adalah dengan melakukan penyuluhan tentang Narkotika. Penyuluh Narkotika dapat disebut juga sebagai komunikator yang akan menyampaikan berbagai informasi seputaran tentang Narkotika sehingga akan mempengaruhi komunikan sebagai orang yang disuluh, hal ini dilakukan demi terlaksananya visi dan misi dari Badan Narkotika Nasional

Maraknya peredaran Narkotika dalam skala jaringan Internasional menjadi perhatian yang cukup serius bagi Indonesia, bahkan untuk di wilayah Sumatera Utara (Sumut), khususnya Kota Medan sudah sangat rawan. Deputi Pemberantasan BNN, Irjen Pol Arman Depari mengatakan, selain jadi tujuan pegiriman narkoba dari Malaysia, Medan juga jadi gudang pengiriman narkoba ke sejumlah wilayah Indonesia. "Sumut merupakan pengguna narkoba terbesar nomor dua di Indonesia. Kota Medan salah satu gudang terbanyak narkobanya untuk dikirim ke wilayah di Indonesia," kata Arman.

Pemulihan korban penyalahgunaan narkoba tidak mudah. Pemulihannya panjang dan mencakup aspek fisik, psikologis, sosial, spiritual, pendidikan, kejuruan, dan hukum. Biaya perawatannya mahal, jumlah bahannya sangat terbatas. Hanya $10 \%$ pecandu narkoba yang mendapatkan akses ke pusat terapi dan rehabilitasi, sebagian besar pecandu berada di masyarakat. Oleh karena itu, perlu untuk mengembangkan upaya pemulihan narkoba berbasis masyarakat yang dapat menjangkau dan melayani pecandu narkoba dan keluarga mereka di masyarakat. Di pusat terapi dan rehabilitasi ini, pengguna narkoba akan dirawat, dan disembuhkan. Berdasarkan hal ini lah, penulis tertarik untuk melakukan penelitian dengan judul " Pola Komunikasi Badan Narkotika Nasional dalam Mencegah Penyebaran Narkoba di Kota Medan.

Berdasarkan uraian di atas, maka permasalahan yang diangkat dalam penelitian ini adalah: Bagaimana pola komunikasi Badan Narkotika Nasional (BNN) dalam mensosialisasikan bahaya Narkoba, pencegahan serta penyalahgunaan Narkoba di Kota Medan?

Penelitian ini bukan penelitian pertama, beberapa penelitian telah dilakukan sebelumnya. diantaranya "Pola Rehabilitasi Islami Bagi Pecandu Narkoba Di Badan Narkotika Nasional Provinsi Riau: Perspektif Konseling Islam”, oleh Zulamri. Kesesuaian pola rehabilitasi dan teknik yang diberikan pada pasien harus memiliki kesesuaian dengan kondisi pasien yang diantaranya adalah faktor kultur tempat individu berkembang, namun dalam konteks penerapannya di Indonesia yang mayoritas penduduknya Islam. Pada dasarnya proses dan teknik rehabilitasi Islam ada tiga tahap yaitu 
Jurnal Komunikasi Universitas Garut: Hasil Pemikiran dan Penelitian

Vol. 7, No. 1, April 2021

Halaman 570-576

tahap pembersihan diri, pengembangan diri, dan penyempurnaan diri, ketrampilan dan keahlian tidak akan datang dan bertambah dengan sendirinya tanpa adanya suatu latihan-latihan. Dalam proses pola rehabilitasi kebanyakan residen tidak bisa diharapkan untuk menyelesaikan masalahnya sendiri. Sehingga diperlukan suatu upaya bantuan guna membantu residen dalam proses pemulihannya, yaitu salah satunya dengan menanamkan nilainilai Islami di dalam diri pecandu narkoba (Zulamri, 2017).

"Sufistic Therapy With Spiritual Emotional Freedom Technique (Seft) Method For Healing The Behavior Of Drugs Addict”, oleh Cintami Farmawati. Penelitian ini adalah untuk mengetahui apakah terapi sufistik dengan metode Spiritual Emotional Freedom Technique (SEFT) dapat menyembuhkan perilaku pecandu yang mencari narkoba. Subjek penelitian adalah 4 (empat) orang pecandu narkoba. Ketergantungan secara fisik terhadap narkoba dapat diatasi dengan memberikan obat-obatan dengan golongan sejenis sebagai pengganti zat yang biasa dikonsumsi untuk meminimalisir gejala putus zat, namun hal yang tersulit adalah mengubah perilaku pecandu yang mencari narkoba dan mengkonsumsi kembali. Penelitian ini menggunakan rancangan multiple baseline design dengan desain $\mathrm{AB}$ follow-up dimana A merupakan baseline, B merupakan terapi sufistik dengan metode SEFT yang meliputi tahapan the set-up, the tune in, dan the tapping, serta follow-up. Analisis data dalam penelitian ini menggunakan analisis kuantitatif dan analisis kualitatif. Analisis kuantitatif dalam penelitian ini berupa penjelasan grafik penelitian, sedangkan analisis kualitatif berupa hasil dari observasi dan wawancara selama penelitian. Hasil penelitian ini menunjukkan bahwa hipotesis diterima dimana terapi sufistik dengan metode SEFT dapat menyembuhkan perilaku (Farmawati, 2019).

"Pola Komunikasi Islam Penyuluh dalam Pencegahan dan Pemberantasan Bahaya Penyalahgunaan Narkoba di Kalangan Remaja Kota Langsa", oleh Muhammad Mukhlis. Permasalahan yang diajukan dalam penelitian ini adalah tentang bagaimana pola komunikasi Islam penyuluh dalam pencegahan dan pemberantasan bahaya penyalahgunaan narkoba di kalangan remaja Kota Langsa, peran penyuluh dalam pencegahan dan pemberantasan bahaya penyalahgunaan narkoba di kalangan remaja Kota Langsa, faktor-faktor penghambat dan yang mendukung dalam pencegahan dan pemberantasan bahaya penyalahgunaan narkoba dikalangan remaja Kota Langsa, dan upaya penyuluh dalam pencegahan dan pemberantasan bahaya penyalahgunaan narkoba dikalangan remaja Kota Langsa.

Tujuan dari penelitian ini adalah 1) untuk mengetahui bagaimana pola komunikasi Islam penyuluh dalam pencegahan dan pemberantasan bahaya penyalahgunaan narkoba dikalangan remaja Kota Langsa, 2) untuk mengetahui peran penyuluh dalam pencegahan dan pemberantasan bahaya penyalahgunaan narkoba dikalangan remaja Kota Langsa, 3) untuk mengetahui faktor-faktor penghambat dan yang mendukung dalam pencegahan dan pemberantasan bahaya penyalahgunaan narkoba dikalangan remaja Kota Langsa, dan 4) untuk mengetahui upaya penyuluh dalam pencegahan dan pemberantasan bahaya 
Jurnal Komunikasi Universitas Garut: Hasil Pemikiran dan Penelitian

Vol. 7, No. 1, April 2021

Halaman 570-576

penyalahgunaan narkoba dikalangan remaja Kota Langsa. Penelitian ini dilakukan dengan menggunakan perspektif penelitian kualitatif dengan metode grounded theory. Metode ini digunakan karena yang menjadi tekanan dalam penelitian ini adalah interaksi sosial antar individu atau kelompok. Sumber data diperoleh secara langsung melalui pihakpihak yang terkait yaitu penyuluh melalui wawancara, observasi serta analisis dokumen. Hasil penelitian menunjukkan bahwa pola komunikasi Islam yang dilakukan penyuluh dalam pencegahan dan pemberantasan bahaya penyalahgunaan narkoba ialah dengan pola komunikasi 1) interpersonal communication (komunikasi antarpribadi) 2) komunikasi kelompok melalui desiminasi, upacara disekolah, 3) serta komunikasi massa melalui radio SCK, GIPSI dan surat kabar. Sedangkan teknik yang digunakan ialah teknik informatif dan persuasif. Selain itu penyuluh memiliki peran manifes dan peran laten dalam pencegahan dan pemberantasan bahaya penyalahgunaan narkoba di kalangan remaja Kota Langsa. Dalam melaksanakan tugasnya penyuluh memiliki hambatan yaitu berbenturan waktu, kekurangan penyuluh, respon remaja yang kurang terhadap penyuluhan, penyalahguna remaja yang tidak konseling sesuai dengan yang diharapkan serta hambatan ekologis. Sedangkan hal yang mendukung ialah dukungan dari masyarakat dan pihak sekolah serta didukung oleh alat-alat yang memudahkan penyuluh menyampaikan pesan kepada remaja. Dalam mengatasi hambatan penyuluh melakukan kerjasama dengan pihak desa dan sekolah, bekerja ekstra untuk menutupi kekurangan penyuluh, serta mendatangi korban penyalahgunaan www.journal.uniga.ac.id yang tidak terus menerus melakukan konseling (Mukhlis, 2013).

\section{Metode Penelitian}

Penelitian ini merupakan penelitian lapangan, menggunakan metode penelitian kualitatif deskriptif. Metode deskriptif dilakukan dengan tujuan untuk mendeskripsikan, menggambarkan, atau melukiskan secara sistematis, faktual serta akurat mengenai fakta-fakta, sifat-sifat serta hubungan antar fenomena yang tengah diselidiki. Teknik pengumpulan akan dilakukan dengan triangulasi (gabungan). Informan penelitian ditentukan melalui metode purposive sumpling. Tehnik pengumpulan data melalui wawancara, observasi, dan dokumentasi. Teknik analisis data secara umum digunakan untuk menjawab rumusan masalah.

\section{Hasil Penelitian dan Pembahasan \\ Pola Komunikasi BNN Dalam Memberantas Penyalahgunaan Narkoba}

Pemerintah memberikan wewenang sepenuhnya kepada BNN sebagai lembaga Non-Kementerian dalam mewujudkan masyarakat Indonesia yang sejahtera, adil dan makmur yang merata baik secara materil dan spiritual berdasarkan pada Pancasila dan Undang-Undang Dasar Negara Republik Indonesia tahun 1945 dan hal ini juga tertuang dalam UndangUndang Nomor 35 tahun 2009. Sumber daya manusia yang berkulaitas harus senantiasa dijaga serta ditingkatkan secara kontiniu, begitu juga dengan tingkat kesehatannya, dan untuk menjaga kesehatan dari sumber daya manusia dibutuhkan salah satu upaya dalam meningkatkan pengobatan serta pelayanan kesehatan yakni dengan memanfaat jenis 
Jurnal Komunikasi Universitas Garut: Hasil Pemikiran dan Penelitian

Vol. 7, No. 1, April 2021

Halaman 570-576

Narkoba tertentu yang dapat dimanfaatkan sebagai obat, dan juga melakukan pencegahan serta pemberantasan bahaya dari penyalahgunaan dan peredaran gelap Narkoba dan Prekursor Narkoba.

BNN dalam menanggulangi kejahatan Narkoba BNN memiliki dua cara yakni; (1) preventif (mencegah sebelum terjadinya kejahatan), dan (2) tindakan represif (usaha sesudah terjadinya kejahatan). BNN telah mengakomodir dan membagi tugas pada bidang yang telah dikategorikan dalam bidang pencegahan dan pemberdayaan masyarakat serta pemberantasan.

Berkaitan dengan pola komunikasi Islam yang dilakukan BNN dalam pencegahan, pemberantasan serta bahaya dari Narkoba di Kota Medan adalah dilakukan dengan cara berkerjasama dengan berbagai pihak, melakukan sosialisasi seiring dengan memutar film yang terkait dengan Narkoba, pembagian buku mengenai penyalahgunaan Narkoba ke sekolah-sekolah, menempelkan poster di tempat tongkrongan anak remaja, serta menggunakan media massa. BNN lebih memfokuskan kegiatan preventif dengan menggunakan bentuk komunikasi penyuluhan dalam kegiatan sosialisasi dan desiminasi yang mengajak kerjasama seluruh dan berbagai elemen dari lapisan masyarakat, sehingga upaya mewujudkan Indonesia bebas Narkoba dapat terlaksana. Tujuan pelaksanaan sosialisai adalah agar masyarakat mengetahui, memahami, menyadari akan bahayanya dari penyalahgunaan Narkoba. Melalui hal tersebut di atas diharapkan adanya perubahan sikap, pendapat, perilaku dan juga perubahan sosial.

Media yang digunakan oleh BNN adalah media massa, dan media digital.
Melalui media massa BNN memproduksi iklan pencegahan dan pemberantasan penyalahgunaan dan peredaran gelap Narkoba, melakukan talkshow melalui Radio. Sedangkan melalui media digital BNN melakukan himbauan tentang bahaya penyalahgunaan Narkoba melalui media sosial. Pemanfaatan penggunaan media masa dan media digital yang dilakukan oleh BNN merupakan hal yang sangat tepat dikarenakan mampu menjangkau khalayak dalam lingkup yang lebih luas walaupun feedback yang dihasilkan tertunda. Penggunaan media massa sebagai media penyebaran informasi dikarenakan media massa secara umum memiliki fungsi sebagai menyiarkan informasi, mendidik, menghibur serta mempengaruhi.

BNN juga lebih menekankan pada kegiatan desiminasi yang membutuhkan kerjasama dengan para kepala desa, dan dalam kegiatan ini peserta yang hadir harus lebih banyak peserta remaja dikarenakan remaja merupakan orang yang rentan dalam penggunaan penyalahgunaan Narkoba karena lebih banyak remaja yang terjerumus dalam penyalahgunaan Narkoba yang disebabkan remaja memiliki sifat energik dan dinamis serta selalu ingin menciba hal yang baru, mental yang belum cukup matang.

Penyuluhan melalui sosialisasi akan dilakukan secara langsung (face to face) secara maksimal dengan cara mengikutsertakan seluruh elemen masyarakat dalam kegiatan ini sehingga BNN dapat menjadi fasilitator.

\section{Kesimpulan}

Berdasarkan hasil penelitian yang dilakukan, dapat diambil kesimpulan bahwa pencegahan bahaya narkoba yang dilakukan Badan Narkotika Nasional 
Jurnal Komunikasi Universitas Garut: Hasil Pemikiran dan Penelitian

Vol. 7, No. 1, April 2021

Halaman 570-576

dilakukan melalui dua cara yakni; (1) preventif (mencegah sebelum terjadinya kejahatan), dengan melakukan penyuluhan kepada masyarakat terkait bahaya narkoba, dan (2) tindakan represif (usaha sesudah terjadinya kejahatan), bekerja sama dengan pihak lain dalam melakukan rehabilitasi terhadap pencandu narkoba.

\section{Daftar Pustaka}

Acep Saifullah. (2013). "Narkoba Dalam Perspektif Hukum Islam dan Hukum Positif: Sebuah Studi Perbandingan." dalam Jurnal Universitas Ibnu Khaldun (UIK) Bogor Volume 11 Nomor 1.

Ardianto, Elvinaro. dkk. 2011. Komunikasi Pembangunan Perubahan Sosial Perspektif Dominan Kaji Ulang dan Teori Kritis. Cet. I.Jakarta: Rajawali.

Arikunto, Suharsimi. (2006). Prosedur Penelitian Suatu Pendekatan Praktik. Jakarta: PT. Rineka Cipta.

Badan Narkotika Nasional Republik Indonesia. (2004). Komunikasi Penyuluhan Pencegahan Penyalahgunaan Narkoba. Jakarta.

Bahri Djamarah, Syaiful. (2004). Pola Komunikasi Orang Tua dan Anak dalam Keluarga. Jakarta: Rineka Cipta.

Buku Advokad Pencegahan Penyalahgunaan Narkoba Bagi Petugas Lapas Dan Rutan, Hlm1, diambil dari situs resmi BNN.

Cangara, H. Hafied. (2007). Pengantar Ilmu Komunikasi, Edisi Revisi. Jakarta: PT. Raja Grafindo Persada.

Chaplin J.P.. (2006). Kamus Lengkap Psikologi, Edisi. I. Jakarta: PT. Raja Grafindo Persada Ma'arif, Bambang S. 2010. Komunikasi Dakwah Paradigma untuk Aksi. Cet. I. Bandung: Simbiosa Rekatama Media.

Cintami Farmawati. (2019). Sufistic Therapy With Spiritual Emotional Freedom Technique (Seft) Method
For Healing The Behavior Of Drugs Addict. Jurnal THEOLOGIA, Vol. 30 No. 1 (2019), 107-126.

Devito, A, J. (1995). The Interpersonal Communication Book, Seventh edition. New York: Harper Collins Cllege Publishers.

Direktorat Diseminasi Informasi. (2012). Deputi Bidang Pencegahan Badan Narkotika Nasional Republik Indonesia, Pencegahan Penyalahgunaan Narkoba Bagi Remaja. Jakarta.

Dorland, W.A.N. (2006). Kamus Kedokteran Dorland (29th ed.). terj.Hartanto, dkk., Jakarta: EGC.

Fitri Yanti. (2013). Pola Komunikasi Islam Terhadap Tradisi Heterodoks (Studi Kasus Tradisi Ruwatan. Jurnal Analisis, Vol. XIII, No. 1, Juni 2013.

Herliani, Lia. (2015). Analisis Pemanfaatan Situs Jejaring Sosial Facebook sebagai Media Promosi Anggota BUSAM (Bubuhan Samarinda), eJournal Ilmu Komunikasi, vol. 3, No. 4.

Hidayat, Dasrun. (2012). Komunikasi Antarpribadi dan Medianya. Yogyakarta: Graha Ilmu.

Hubeis, Musa dkk. 2012. Komunikasi Profesional. Bogor : IPB Press.

Jehani, L., \& Antoro. (2008). Mencegah Terjerumus Narkoba. Jakarta: Visimedia.

Kholil, Syukur. (2006). Metodologi Penelitian Komunikasi, Cet. I. Bandung: Cita Pustaka Media.

Kriyantono, Rachmat. (2010). Teknis Praktis Riset Komunikasi, Cet. 5 Edisi. I. Jakarta: Kencana.

Liliweri, Alo. (2015). Komunikasi Antarpersonal. Jakarta: Kencana Prenada Media Group.

Moleong, Lexy J. (2006). Metodelogi Penelitian Kualitatif, Cet. XXII. Bandung: PT. Remaja Rosdakarya. 
Jurnal Komunikasi Universitas Garut: Hasil Pemikiran dan Penelitian

Vol. 7, No. 1, April 2021

Halaman 570-576

Muhammad, Mukhlis. (2013). Pola

Komunikasi Islam Penyuluh dalam

Pencegahan dan Pemberantasan

Bahaya Penyalahgunaan Narkoba

di Kalangan Remaja Kota Langsa.

Tesis Program Pascasarjana IAIN

Sumatera Utara Medan.

Mulyana, Deddy. (2010). Ilmu

Komunikasi Suatu Pengantar, Cet.

XIV. Bandung: PT. Remaja

Rosdakarya.

Nugroho, dkk. (2018). Rehabilitation Patterns to Teens Victims Through

Religious, Social Economics, And

Education Perspective Approach.

Advances in Social Science,

Education and Humanities

Research, volume 115.

Rakhmat, Jalaluddin. (2011). Psikologi

Komunikasi. Bandung : PT Remaja Rosdakarya.

Ruben, Brent D. dkk. (2013). Komunikasi dan Prilaku Manusia. Jakarta: Raja Grafindo Persada.

Zulamri. (2017). Pola Rehabilitasi Islami Bagi Pecandu Narkoba Di Badan Narkotika Nasional Provinsi Riau: Perspektif Konseling Islam. Jurnal Risalah, Juni Vol. 28, No. 1. 